\title{
Treatment of Gastroparesis: An Update
}

\author{
Vivek Gumaste Joel Baum \\ Department of Medicine, Mount Sinai Services at Elmhurst, Elmhurst General Hospital, Elmhurst, N.Y., and \\ Mount Sinai School of Medicine of the City University of New York, New York, N.Y., USA
}

\section{Key Words}

Gastroparesis · Diabetes

\begin{abstract}
Gastroparesis is a chronic disorder of gastric motility that is characterized by delayed emptying of either solids or liquids from the stomach in the absence of any mechanical obstruction. Nausea, vomiting, early satiety and bloating are some of the manifestations of gastroparesis. Idiopathic, diabetes mellitus and postsurgical states account for the majority of cases. Gastroparesis is a difficult condition to treat. Prokinetic drugs like metoclopramide and erythromycin form the mainstay of therapy but are less than ideal. Some patients may benefit from endoscopic botolinium toxin injection. Gastric electrical stimulation, though promising, is not ready for prime time yet.

Copyright $\odot 2008$ S. Karger AG, Basel
\end{abstract}

Gastroparesis is a chronic disorder of gastric motility that is characterized by delayed emptying of either solids or liquids from the stomach in the absence of any mechanical obstruction. Gastroparesis assumes clinical importance because it can contribute to upper gastrointestinal symptoms like nausea, vomiting and early satiety.

The precise incidence of gastroparesis is not known, but it is estimated to affect about $4 \%$ of the population [1]. Gastroparesis, as documented by delayed gastric empty- ing scintigraphy, is present in $25-55 \%$ of patients with type 1 diabetes and in $30 \%$ of those with type 2 diabetes [2-5]. Considering the widespread prevalence of diabetes, this would constitute a significant proportion of the population.

\section{Etiology}

The etiology of gastroparesis is diverse with the idiopathic variety constituting the largest group in one study [6]. Diabetes accounted for $29 \%$ of patients in that same report with postsurgical causes making up 13\%. These 3 causes (idiopathic, diabetes and postsurgical) account for a majority of all cases. Other causes of gastroparesis include neurological conditions like Parkinsonism, collagen vascular diseases, Chagas disease, hypothyroidism, hyperparathyroidism and hypoparathyroidism.

\section{Clinical Manifestations and Diagnosis}

Present studies indicate that the majority of those with delayed gastric emptying are women and the mean age of onset is 34 years [6].

Gastroparesis manifests itself through a combination of symptoms. Most symptoms are nonspecific and overlap with common gastrointestinal disorders like peptic ulcer disease and nonulcer dyspepsia. Nausea/vomiting,

\section{KARGER \\ Fax +4161306 1234 \\ E-Mail karger@karger.ch}

www.karger.com
(C) 2008 S. Karger AG, Basel

0012-2823/08/0784-0173\$24.50/0

Accessible online at:

www.karger.com/dig
Assoc. Prof. Vivek Gumaste, MD

Mount Sinai School of Medicine

Division of GI, Elmhurst General Hospital

79-01 Broadway, New York, NY 11373 (USA)

Tel. +1 718334 2288, Fax +1 718334 1738, E-Mail gumastev@yahoo.com 
Table 1. Proposed classification of gastroparesis severity

Grade 1: Mild gastroparesis

Symptoms relatively easily controlled

Able to maintain weight and nutrition on a regular diet or minor dietary modifications

Grade 2: Compensated gastroparesis

Moderate symptoms with partial control with pharmacological agents

Able to maintain nutrition with dietary and lifestyle adjustments Rare hospital admissions

Grade 3: Gastroparesis with gastric failure

Refractory symptoms despite medical therapy

Inability to maintain nutrition via oral route

Frequent emergency room visits or hospitalizations

Reproduced from Abel et al. [9].

postprandial fullness/early satiety and bloating are the commonest manifestations. Nausea is the most consistent symptom found in over $90 \%$ of patients [6, 7]. Bloating and early satiety are present to a lesser degree, being found in $75 \%$ and $60 \%$, respectively, in one study [6].

Abdominal pain may be present in $46-89 \%$ of patients but is unlikely to be the predominant symptom $[6,7]$.

As the symptoms are nonspecific with a significant degree of overlap with other gastric disorders, the initial work-up should include an upper endoscopy, even if gastroparesis is strongly suspected. This is necessary to rule out any mechanical obstruction and other common disorders like peptic ulcer diseases and nonulcer dyspepsia.

When an upper endoscopy does not reveal any organic obstruction and the endoscopic findings do not adequately explain the patient's symptoms, a definitive test to diagnose gastroparesis such as gastric scintigraphy must be done.

\section{Assessment of Severity}

Assessment of severity is important for appropriate management. One method is the Gastroparesis Cardinal Symptom Index (GCSI), which is a sum, total of 3 subscales (ranging from 1-3) for the 3 main symptom complexes: postprandial fullness/early satiety, nausea/vomiting and bloating [8].

Another simple gradation of severity is outlined in table 1 [9]. Grade 1 usually includes patients with mild
Table 2. Medications associated with impaired gastric emptying

Narcotic pain medications

Tricyclic antidepressants

Calcium channel-blocking medications

Clonidine

Dopamine agonists

Lithium

Nicotine

Progesterone containing medications

Muscarinic cholinergic receptor antagonists

intermittent symptoms that are controlled with diet modification and avoidance of exacerbating agents. Grade 2 patients have moderately severe symptoms but no weight loss and require prokinetic drugs plus antiemetic agents for control. In Grade 3, patients are refractory to medication, unable to maintain oral nutrition and require frequent emergency room visits. These patients require intravenous fluids, medications, enteral or parenteral nutrition and endoscopic or surgical therapy.

\section{Treatment}

A wide array of therapeutic interventions is available to treat gastroparesis. Diet modification, pharmacological agents, endoscopic techniques, surgery and psychological counseling are some of the modalities employed.

\section{General and Dietary Measures}

While there are no controlled trials testing the efficacy of diet modification in the therapy of gastroparesis, some dietary recommendations may prove helpful in patients with milder forms of the disease. Multiple small meals a day as opposed to 2 or 3 large meals facilitate gastric emptying. Generous intake of fluids during a meal may aid gastric emptying, as liquids empty more rapidly than solids. An overall reduction in the solid food content is also advised. A diet low in fats decreases the inhibitory effect of lipids on gastric emptying. Patients should be told to avoid a high fiber diet to prevent phytobezoar formation.

Proper mastication and postprandial walking are additional factors that may facilitate the gastric emptying process. 
Table 3. Prokinetic agents

\begin{tabular}{|c|c|c|}
\hline Agent & Mechanism & Dosage \\
\hline Metaclopramide & $\begin{array}{l}\text { dopamine } \mathrm{D}_{2} \text { receptor } \\
\text { antagonist }\end{array}$ & 5-20 mg q.i.d. \\
\hline Domperidine & $\begin{array}{l}\text { dopamine } \mathrm{D}_{2} \text { receptor } \\
\text { antagonist }\end{array}$ & 10-30 mg q.i.d. \\
\hline Erythromycin & motilin receptor agonist & 50-250 mg q.i.d. \\
\hline Bethanechol & muscarinic receptor agonist & 25 mg q.i.d. \\
\hline Pyridostigmine & acetylcholinestrase inhibitor & $30-60$ mg t.i.d. \\
\hline Tegaserod & $5-\mathrm{HT}_{4}$ receptor agonist & withdrawn in US \\
\hline Cisapride & $5-\mathrm{HT}_{4}$ receptor agonist & withdrawn in US \\
\hline Loxiglumide & CCK receptor antagonist & under study \\
\hline
\end{tabular}

Medicines that decrease gastric motility should be discontinued if possible (table 2). Identification and correction of the underlying cause of gastroparesis may be helpful in some cases. In diabetics, aggressive control of blood sugar is advocated as it is thought to facilitate the action of other therapeutic measures.

\section{Prokinetic Agents}

There are 3 broad classes of prokinetic agents used in the treatment of gastroparesis: dopamine receptor antagonists, motilin receptor agonists and $5-\mathrm{HT}_{4}$ receptor agonists (table 3).

\section{Dopamine Receptor Antagonists}

Metaclopramide. Metaclopramide is a $5-\mathrm{HT}_{4}$ agonist, a dopamine $\mathrm{D}_{2}$ receptor antagonist and a direct stimulant of smooth muscle, all of which contributes to its prokinetic effect [1]. In addition to accelerating gastric motility, metaclopramide has an independent antiemetic effect. Metaclopramide can be administered intravenously, subcutaneously or through the oral route. A liquid preparation is also available.

Although there are several studies [10-18] that have attempted to document the efficacy of metoclopramide in gastroparesis, most of them suffer from significant design flaws or insufficient numbers. Some of the more acceptable trials are listed in table 4 . The overall conclusion that can be drawn from these trials is that a minority of patients may experience symptom benefit from metoclopramide therapy. However, there appears to be poor correlation between the improvement in gastric emptying and reduction of symptoms.

When compared to erythromycin, metoclopramide proved to be inferior in terms of symptom relief in one
Table 4. Efficacy of metoclopramide in gastroparesis

\begin{tabular}{|c|c|c|c|c|}
\hline Study & $\mathrm{n}$ & Design & $\begin{array}{l}\text { Symptom } \\
\text { reduction }\end{array}$ & $\begin{array}{l}\text { GE im- } \\
\text { provement }\end{array}$ \\
\hline Perkel et al. [13] & 28 & RDBP & yes & not stated ${ }^{1}$ \\
\hline Snape et al. [12] & 10 & RDBP & yes & yes \\
\hline McCallum et al. [11] & 40 & DBP & yes & yes \\
\hline Ricci et al. [14] & 13 & $\mathrm{RDBP}$ & yes & yes \\
\hline \multicolumn{5}{|c|}{ Metoclopramide vs. cisapride } \\
\hline De Caestecker et al. [15 & 19 & DBP & No & no \\
\hline \multicolumn{5}{|c|}{ Metoclopramide (M) vs. erythromycin (E) } \\
\hline Erbas et al. [16] & 13 & $\mathrm{OL}$ & yes $(\mathrm{E}>\mathrm{M})$ & yes \\
\hline \multicolumn{5}{|c|}{ Metoclopramide (M) vs. domperidone (D) } \\
\hline Patterson et al. [18] & 45 & RDB & yes & not studied \\
\hline Dumitrascu et al. [17] & 10 & DB & yes $(D>M)$ & yes $(\mathrm{D}>\mathrm{M})$ \\
\hline \multicolumn{5}{|c|}{$\begin{array}{l}\mathrm{GE}=\text { Gastric emptying; } \mathrm{RDBP}=\text { randomized double-blind } \\
\text { placebo controlled; } \mathrm{DBP}=\text { double-blind placebo controlled; } \mathrm{OL}= \\
\text { open label; } \mathrm{RDB}=\text { randomized double blind; } \mathrm{DB}=\text { double blind. } \\
{ }^{1} \text { Used barium studies to measure gastric emptying. }\end{array}$} \\
\hline
\end{tabular}

study [16]. Other studies $[17,18]$ have shown that metoclopramide may be equally effective or marginally inferior to domperidone in efficacy.

Patients may develop tolerance over time and uncomfortable side effects may limit its use in up to $30 \%$ of patients. Irreversible tardive dyskinesia is a serious side effect that occurs in $1-10 \%$ of patients treated for more than 3 months [19]. Therefore, it is not advisable to maintain patients on metaclopramide for a prolonged period. When initiating therapy, the side effects should be discussed and documented in the patient record.

Domperidone. Domperidone is a peripheral dopamine $\mathrm{D}_{2}$ receptor antagonist with prokinetic properties and a potent antiemetic effect. As it does not cross the bloodbrain barrier, its central nervous system side effects are minimal.

In clinical trials, the efficacy of domperidone matches that of metaclopramide and cisapride [18]. However, its effect on solid-phase gastric emptying is lost by 6 weeks [20]. The drug is not approved in the United States by the FDA but can be made available through special application for patients with refractory gastroparesis.

\section{Motilin Receptor Agonists}

Erythromycin. Erythromycin exerts its prokinetic effect by stimulating the motilin receptors on smooth muscles and neurons in the gastroduodenal area [21]. How- 
ever, unlike metaclopramide, erythromycin has no independent antiemetic effect.

Most published trials [22-26] reporting on the efficacy of erythromycin in gastroparesis have been open labeled, had inadequate numbers or lacked strict definitions [22]. A few representative studies are outlined in table 5. The conclusion gleaned from these reports is that though erythromycin improves gastric emptying, it benefits only a minority of patients with regard to symptom amelioration.

Erythromycin can be administered intravenously in hospitalized patients or provided in liquid form or oral tablets to outpatients. Its most potent effect is seen when injected intravenously [27]. The oral route $(125-250 \mathrm{mg}$, 3-4 times daily) is less efficacious. Tolerance is known to occur with chronic use. An increased incidence of sudden cardiac death in patients using erythromycin has been reported [28].

Other Motilin Receptor Agonists. Mitemcinal, a new motilin agonist, which can be administered orally, has shown promise in initial trials [29]. Ghrelin, an endogenous neurohumoral mediator, is currently under study [30].

\section{5- $\mathrm{HT}_{4}$ Receptor Agonists}

Tegaserod and Cisapride are $5-\mathrm{HT}_{4}$ receptor agonists, which have been used to treat gastroparesis in the past. Both agents were withdrawn from use in the United States owing to serious cardiovascular complications [1].

\section{Symptomatic Therapy}

Antiemetic drugs have been used successfully in clinical practice to treat the symptoms of gastroparesis although hard evidence for this rationale in the form of scientific studies is minimal. The most commonly used antiemetic drugs are the phenothiazines (for example prochlorperazine and thiethylperazine) and they can be used in conjunction with prokinetic agents [9].

Low-dose tricyclic antidepressants may provide relief of symptoms in patients with gastroparesis [31].

Pain may be a prominent symptom in some patients. Nonsteroidal agents, selective serotonin reuptake inhibitors and opiates have been used with varying degrees of success [9].

\section{Endoscopic Treatment}

In some patients with gastroparesis, pylorospasm may contribute to a delay in gastric emptying. Endoscopic therapy involves the injection of botulinium toxin (100200 units in a circumferential pattern; 4 injections around
Table 5. Efficacy of erythromycin in gastroparesis

\begin{tabular}{llllll}
\hline Study & $\mathrm{n}$ & Design & Route & $\begin{array}{l}\text { Symptom } \\
\text { reduction }\end{array}$ & $\begin{array}{l}\text { GE improve- } \\
\text { ment }\end{array}$ \\
\hline Richards et al. [25] & 10 & OL & PO, IV & yes & yes \\
Ramirez et al. [24] & 16 & OL & PO, IV & yes & yes \\
Fiorucci et al. [23] & 12 & OL & IV & not stated & yes \\
Samsom et al. [26] & 12 & DBC & PO & unclear & not done
\end{tabular}

$\mathrm{GE}=$ Gastric emptying; $\mathrm{OL}=$ open label; $\mathrm{PO}=$ per os; $\mathrm{IV}=$ intravenous; $\mathrm{DBC}=$ double-blind controlled.

Table 6. Overview of studies with botulinium toxin injection in gastroparesis

\begin{tabular}{|c|c|c|c|c|c|}
\hline Study & $\mathrm{n}$ & Dose & Follow-up & $\begin{array}{l}\text { Symp- } \\
\text { tom re- } \\
\text { duction }\end{array}$ & $\begin{array}{l}\text { GE } \\
\text { improve- } \\
\text { ment }\end{array}$ \\
\hline \multicolumn{6}{|l|}{ Open } \\
\hline Ezzedine et al. [33] & 6 & $100 \mathrm{IU}$ & 6 weeks & $55 \%$ & $52 \%$ \\
\hline Miller et al. [34] & 10 & $100 \mathrm{IU}$ & 4 weeks & $38 \%$ & $48 \%$ \\
\hline Arts et al. [36] & 20 & $100 \mathrm{IU}$ & 1 month & $29 \%$ & $35 \%$ \\
\hline Lacy et al. [35] & 8 & $200 \mathrm{IU}$ & 12 weeks & $55 \%$ & $33 \%$ \\
\hline Bromer et al. [32] & 63 & $200 \mathrm{IU}$ & 2 months & $43 \%$ & NS \\
\hline \multicolumn{6}{|c|}{ Randomized placebo-controlled trials } \\
\hline Arts et al. [38] & 23 & $100 \mathrm{IU}$ & 1 month & none & none \\
\hline Friedenberg et al. [39] & 16 & $200 \mathrm{IU}$ & 1 month & none & $\begin{array}{l}\text { im- } \\
\text { proved }\end{array}$ \\
\hline
\end{tabular}

$\mathrm{GE}=$ Gastric emptying; NS = not significant.

Table 7. Trials with gastric electrical stimulation

\begin{tabular}{|c|c|c|c|c|}
\hline Study & Design & $\mathrm{n}$ & $\begin{array}{l}\text { Duration } \\
\text { months }\end{array}$ & $\begin{array}{l}\text { Symptom } \\
\text { improvement }\end{array}$ \\
\hline GEMS [42] & open & 33 & 12 & yes \\
\hline \multirow[t]{2}{*}{ WAVESS [43] } & DBS & 33 & 2 & yes \\
\hline & open & 33 & 12 & yes \\
\hline Forster et al. [40] & open & 25 & 12 & $\begin{array}{l}\text { improved at } 3 \text { months } \\
\text { sustained at } 12 \text { months }\end{array}$ \\
\hline Forster et al. [44] & open & 55 & 12 & $\begin{array}{l}\text { improved at } 6 \text { months } \\
\text { not sustained at } \\
12 \text { months }\end{array}$ \\
\hline Lin et al. [45] & open & 55 & 36 & $\begin{array}{l}\text { improved at } 1 \text { year } \\
\text { sustained for } 3 \text { year }\end{array}$ \\
\hline Anand et al. [46] & open & 214 & 48 & sustained for 4 year \\
\hline
\end{tabular}

DBS $=$ Double-blind sham. 
Table 8. Consensus recommendations for the treatment of gastroparesis

\begin{tabular}{|c|c|c|c|c|c|}
\hline $\begin{array}{l}\text { Psychological } \\
\text { measures }\end{array}$ & Glycemic control & Nutritional care & Prokinetic medications & Antiemetic therapy & Pain control \\
\hline $\begin{array}{l}\text { Empathy and } \\
\text { education } \\
\text { Patient support } \\
\text { groups } \\
\text { Behavioral or } \\
\text { relaxation therapy } \\
\text { Hypnosis }\end{array}$ & $\begin{array}{l}\text { Twice daily long- } \\
\text { acting insulin plus } \\
\text { periprandial short- } \\
\text { acting insulin } \\
\text { Insulin pump } \\
\text { Pancreas transplant }\end{array}$ & $\begin{array}{l}\text { Small, frequent meals, } \\
\text { low in fat and fiber } \\
\text { Primarily liquid diet } \\
\text { Liquid nutrient } \\
\text { supplements } \\
\text { Enteral feedings } \\
\text { Central or peripheral } \\
\text { parenteral nutrition } \\
\text { short term }\end{array}$ & $\begin{array}{l}\text { Metoclopramide or } \\
\text { erythromycin PRN } \\
\text { Metoclopramide or } \\
\text { erythromycin scheduled } \\
\text { dosing } \\
\text { Domperidone or } \\
\text { tegaserod } \\
\text { Pyloric botulinum toxin }\end{array}$ & $\begin{array}{l}\text { Phenothiazine or dopamine } \\
\text { receptor antagonist PRN } \\
\text { Muscarinic receptor } \\
\text { antagonist or } 5-\mathrm{HT}_{3} \\
\text { antagonist } \\
\text { Tricyclic agents } \\
\text { Tetrahydrocannabinol, } \\
\text { lorazepam or alternative } \\
\text { therapies } \\
\text { Gastric electrical } \\
\text { stimulation }\end{array}$ & $\begin{array}{l}\text { Acetaminophen or } \\
\text { nonsteroidal agents } \\
\text { Tramadol or } \\
\text { propoxyphene } \\
\text { Tricyclic agents } \\
\text { Newer antidepressants } \\
\text { TCAs, SNRIs } \\
\text { Fentanyl patch or } \\
\text { methadone } \\
\text { Referral for pain specialist } \\
\text { Nerve block }\end{array}$ \\
\hline
\end{tabular}

A stepped care approach in a top-down vertical manner is recommended which is dependent on the severity of gastroparesis. Treatment from different categories (columns) is often used in combination. TCA = Tricyclic antidepressant agent; SNRI = selective norepinephrine reuptake inhibitor. Reproduced from Abel et al. [9].

the pylorus) into the pyloric area, which is thought to decrease pylorospasm and accelerate gastric emptying.

Several open-labeled studies [32-37] indicated a good symptomatic response (table 6) with symptom scores falling by $29-55 \%$. Gastric emptying rates also registered a marked improvement (33-52\%) and correlated well with symptom reduction. The effect of botulinium toxin lasted up to 5 months in one study [32].

However, the results from 2 randomized, placebocontrolled trials $[38,39]$ have not been encouraging. Arts et al. [38] failed to demonstrate any beneficial effect on either gastric emptying or symptoms over placebo. In the study by Friedenberg et al. [39], gastric emptying rates improved, but provided no symptom benefit. More studies are required before reaching a final verdict on botulinium toxin injection therapy.

Dilation of the pylorus may produce the same benefit as botulinium injection [1].

\section{Gastric Electrical Stimulation}

Using exogenous electrical current to stimulate the stomach in patients with gastroparesis is a logical and attractive concept. Initial methods involved external leads, which were too large for implantation and unwieldy [40]. Recently, the FDA has given limited approval on humanitarian grounds for a gastric electrical stimulator with a pulse generator that can be implanted into the abdominal wall (Enterra gastric electrical stimulation system). The pulse generator delivers low-energy, high-frequency stimuli and has a battery life of 6-8 years [41]. This method is, at present, limited to a few centers.

Treatment of Gastroparesis
Initial experience with gastric stimulators was obtained through 2 multicenter trials, the Gastric Electrical Mechanical Stimulation Study (GEMS) [42] and the Worldwide Anti-Vomiting Electrical Stimulation Study (WAVESS) [43]. GEMS was a multicenter open-labeled trial that documented improvement in nausea and vomiting in gastroparetic patients. WAVESS was a controlled double-blind sham stimulation trial that reaffirmed the efficacy of gastric stimulation and paved the way for FDA approval of the Enterra system.

All trials $[40,44-46]$ have produced encouraging results with patients experiencing $75-80 \%$ reduction in symptoms (table 7). While some initial studies showed conflicting results with regard to sustenance of improvement $[40,44]$, two subsequent studies have indicated long-term benefits lasting 3 and 4 years, respectively [45, 46]. Cutts et al. [47] were able to demonstrate that gastric stimulation therapy is superior to intensive medical treatment.

About $10 \%$ of patients, however, develop complications like infection, which invariably warrants removal of the device. Other adverse events noted include: lead dislodgement, wire breakage, penetration of the stomach and intestinal obstruction, all of which require surgical intervention [41].

New methods that involve electrodes that can be placed orally by endoscopy or through a percutaneous endoscopic gastrostomy [48] or by percutaneous techniques [49] are also being explored.

Gastric electric stimulation is not ready for prime time yet. Available devices need to undergo further refinement

Digestion 2008;78:173-179 
and easier electrode implantation techniques that obviate the need for surgery are required. Long-term controlled studies involving larger numbers will be necessary for gastric electrical stimulation to be accepted as standard therapy [50, 51].

\section{Surgery}

Extreme cases may require surgical intervention, and operations like partial gastrectomy and pyloroplasty have been performed to treat resistant gastroparesis. The results are unproven so far.

Rarely, a venting gastrostomy may be placed to release the discomfort from gas and liquids [1].

\section{Enteral and Parenteral Nutrition}

Some patients with severe refractory gastroparesis may need enteral or parenteral modes of nutritional support. Enteral nutrition is usually indicated in patients with significant malnutrition ( $>10 \%$ weight loss over 6 months), evidence of mineral deficiencies and electrolyte imbalance and in those who require frequent hospitalizations [1].
Total parenteral nutrition maybe necessary in patients who have concomitant intestinal motility.

\section{Psychological Support}

Anxiety, depression and somatization are increasingly found in patients with severe gastroparesis and appropriate psychological support is necessary to improve the overall well-being of the patient. Psychotherapeutic measures like relaxation techniques have been useful. Some patients benefit from hypnosis and biofeedback [9].

\section{Conclusion}

Most therapeutic measures available to treat gastroparesis are less than ideal and patients may require a combination of measures depending on the severity of their condition. Table 8 summarizes the overall approach to the treatment of gastroparesis.

\section{References}

1 Hasler WL: Gastroparesis: Symptoms, Evaluation, and Treatment. Gastroenterol Clin N Am 2007;36:619-647.

2 Kong M-F, Horowitz M, Jones KL, et al: Natural history of diabetic gastroparesis. Diabetes Care 1998;22:503-507.

>3 Nowak TV, Johnson CP, Kalbfleisch JH, et al: Highly variable gastric emptying in patients with insulin dependent diabetes mellitus. Gut 1995;37:23-29.

4 Moldovan C, Dumitrascu DL, Demian L, et al: Gastroparesis in diabetes mellitus: an Ultrasonographic study. Rom J Gastroenterol 2005; 14:19-22.

5 Horowitz M, Su YC, Rayner CK, et al: Gastroparesis: prevalence, clinical significance and treatment. Can J Gastroenterol 2001;15: 805-813.

6 Soykan I, Sivri B, Saosiek I, et al: Demography, clinical characteristics, psychological and abuse profiles, treatment, and long term follow-up of patients with gastroparesis. Dig Dis Sci 1998;43:2398-2404.

$\checkmark 7$ Hoogerwerf WA, Pasricha PJ, Kalloo AN, et al: Pain: the overlooked symptom in gastroparesis. Am J Gastroenterol 1999;94:10291033.

8 Revicki DA, Rentz AM, Dubois D, et al: Development and validation of a patient-assessed gastroparesis symptom severity measure: the Gastroparesis Cardinal Symptom Index. Aliment Pharmacol Ther 2003;18: 141-150.
$>$

Abel TL, Bernstein RK, Cutts T, et al: Treatment of gastroparesis: a multidisciplinary clinical review. Neurogastroenterol Motil 2006;18:263-283.

10 Parkman HP, Hasler WL, Fisher RS: American Gastroenterological Association technical review on the diagnosis and treatment of gastroparesis. Gastroenterology 2004, 127: 1592-1622.

11 McCallum RW, Ricci DA, Rakatansky H, et al: A multicenter placebo-controlled clinical trial of oral metoclopramide in diabetic gastroparesis. Diabetes Care 1983;6:463-467.

-12 Snape WJ Jr, Battle WM, Schwartz SS, Braunstein SN, Goldstein HA, Alavi A: Metoclopramide to treat gastroparesis due to diabetes mellitus: a double-blind, controlled trial. Ann Intern Med 1982;96:444-446.

13 Perkel MS, Moore C, Hersh T, Davidson ED: Metoclopramide therapy in patients with delayed gastric emptying: a randomized, double-blind study. Dig Dis Sci 1979;24:662666.

14 Ricci DA, Saltzman MB, Meyer C, Callachan C, McCallum RW: Effect of metoclopramide in diabetic gastroparesis. J Clin Gastroenterol 1985;7:25-32.

15 de Caestecker JS, Ewing DJ, Tothill P, Clarke BF, Heading RC: Evaluation of oral cisapride and metoclopramide in diabetic autonomic neuropathy: an eight-week double-blind crossover study. Aliment Pharmacol Ther 1989;3:69-81.
16 Erbas T, Varoglu E, Erbas B, Tastekin G, Akalin S: Comparison of metoclopramide and erythromycin in the treatment of diabetic gastroparesis. Diabetes Care 1993;16: 1511-1514.

17 Dumitrascu DL, Weinbeck M: Domperidone versus metoclopramide in the treatment of diabetic gastroparesis. Am J Gastroenterol 2000;95:316-317.

18 Patterson D, Abell T, Rothstein R, Koch K, Barnett J: A double-blind multi-center comparison of domperidone and metaclopramide in the treatment of diabetic patients with symptoms of gastroparesis. Am J Gastroenterol 1999;94:1230-1234.

19 Ganzini L, Casey DE, Hoffman WL, et al: The prevalence of metaclopramide-induced tardive dyskinesia and acute extrapyramidal movement disorders. Arch Intern Med 1993; 153:1469-1475.

$>20$ Horowitz M, Harding PE, Chatterton BE, Collins PJ, Sherman DJC: Acute and chronic effects of domperidone on gastric emptying in diabetic autonomic neuropathy. Dig Dis Sci 1985;30:1-9.

21 Peters TL: Erythromycin and other macrolides as prokinetic agents. Gastroenterology 1993;105:1886-1899.

22 Maganti K, Onyemere K, Jones MP: Oral erythromycin and symptomatic relief of gastroparesis: a systematic review. Am J Gastroenterol 2003;98:259-263. 
-23 Fiorucci S, Distrutti E, Bassotti G, et al: Effect of erythromycin administration on upper gastrointestinal motility in scleroderma patients. Scand J Gastroenterol 1994;29:807813.

-24 Ramirez B, Eaker EY, Drane WE, et al: Erythromycin enhances gastric emptying in patients with gastroparesis after vagotomy and antrectomy. Dig Dis Sci 1994;39:22952300 .

-25 Richards RD, Davenport K, McCallum RW: The treatment of idiopathic and diabetic gastroparesis with acute intravenous and chronic oral erythromycin. Am J Gastroenterol 1993;88:203-207.

-26 Samsom M, Jebbink RJ, Akkermans LM, et al: Effects of oral erythromycin on fasting and postprandial antroduodenal motility in patients with type I diabetes, measured with an ambulatory manometric technique. Diabetes Care 1997;20:129-134.

-27 Camilleri M: The current role of erythromycin in the clinical management of gastric emptying disorders. Am J Gastroenterol 1993;88:169-171.

-28 Ray WA, Murray KT, Meredith S, et al: Oral erythromycin and the risk of sudden death from cardiac causes. N Engl J Med 2004;351: 1089-1096.

-29 McCallum RW, Cynshi O; US Investigative Team: Efficacy of mitemcinal, a motilin agonist, on gastrointestinal symptoms suggesting diabetic gastropathy: a randomized, multi-center, placebo-controlled trial. Aliment Pharmacol Ther 2007;26:107-116.

-30 Murray CD, Martin NM, Patterson M, et al: Ghrelin enhances gastric emptying in diabetic gastroparesis: a double blind, placebo controlled, crossover study. Gut 2005;54: 1693-1698.

-31 Sawhney MS, Prakash C, Lustman PJ, Clouse RE: Tricyclic antidepressants for persistent or recurrent vomiting in diabetic patients. Gastroenterology 2001;120:A243.

\2 Bromer MQ, Friedenberg F, Miller LS, et al: Endoscopic pyloric injection of botulinium toxin A for the treatment of refractory gastroparesis. Gastrointest Endosc 2005;61: 833-839.
33 Ezzeddine D, Jit R, Katz N, Gopalswamy N, Bhutani MS: Pyloric injection of botulinum toxin for treatment of diabetic gastroparesis Gastrointest Endosc 2002;55:920-923.

>34 Miller LS, Szych GA, Kantor SB, et al: Treatment of idiopathic gastroparesis with injection of botulinum toxin into the pyloric sphincter muscle. Am J Gastroenterol 2002; 97:1653-1660.

35 Lacy BE, Crowell MD, Schettler-Duncan A, Mathis C, Pasricha PJ: The treatment of diabetic gastroparesis with botulinum toxin injection of the pylorus. Diabetes Care 2004 27:2341-2347.

-36 Arts J, van GS, Caenepeel P, Verbeke K, Janssens J, Tack J: Influence of intrapyloric botulinum toxin injection on gastric emptying and meal-related symptoms in gastroparesis patients. Aliment Pharmacol Ther 2006;24: 661-667.

37 Coleski R, Hasler W: Clinical and gastric functional predictors of symptom response to pyloric injection of botulinium toxin in patients with gastroparesis. Neurogastroenterol Motil 2005;17:268.

38 Arts J, Holvoet L, Caenepeel P, Bisschops R, Sifrim D, Verbeke K, Janssens J, Tack J: Clinical trial: a randomized-controlled crossover study of intrapyloric injection of botulinum toxin in gastroparesis. Aliment Pharmacol Ther 2007;26:1251-1258.

39 Friedenberg FK, Palit A, Parkman HP, Nelson D: Randomized, placebo-controlled trial of botulinum toxin A for the treatment of delayed gastric emptying. Gastroenterology 2007;132:M1150.

$>40$ Forster J, Sarosiek I, Delcore R, Lin Z, Raju GS, MaCallum RW: Gastric pacing is a new surgical treatment for gastroparesis. Am J Surg 2001;182:676-681.

-41 Maranki J, Parkman HP: Gastric electrical stimulation for the treatment of gastroparesis. Curr Gastroenterol Rep 2007;9:286294.

42 Abell TL, Van Cutsem E, Abrahamsson H, Huizinga JD, Konturek JW, Galmiche JP, Voeller G, Filez L, Everts B, Waterfall WE, Domschke W, Bruley des Varannes S, Familoni BO, Bourgeois IM, Janssens J, Tougas G: Gastric electrical stimulation in intractable symptomatic gastroparesis. Digestion 2002;66:204-212.
43 Abell T, McCallum R, Hocking M, Koch K, Abrahamsson H, Leblanc I, Lindberg G, Konturek J, Nowak T, Quigley EM, Tougas G, Starkebaum W: Gastric electrical stimulation for medically refractory gastroparesis. Gastroenterology 2003;125:421-428.

44 Forster J, Sarosiek I, Lin Z, et al: Further experiences with gastric stimulation to treat drug refractory gastroparesis. Am J Surg 2003;186:690-695.

45 Lin Z, Sarosiek I, Forster J, McCallum RW: Symptom responses, long-term outcomes and adverse events beyond 3 years of high frequency gastric electrical stimulation for gastroparesis. Neurogastroenterol Motil 2006;18:18-27.

46 Anand C, Al-Juburi A, Familoni B, Rashed H, Cutts T, Abidi N, Johnson WD, Minocha A, Abell TL: Gastric electrical stimulation is safe and effective: a long-term study in patients with drug-refractory gastroparesis in three regional centers. Digestion 2007;75: 83-89.

47 Cutts TF, Luo J, Starkebaum W, Rashid H, Abell TL: Is gastric electrical stimulation superior to standard pharmacologic therapy in improving GI symptoms, healthcare resources, and long-term health care benefits? Neurogastroenterol Motil 2005;17:35-43.

48 Ayinala S, Batista O, Goyal A, et al: Temporary gastric electrical stimulation with orally or PEG-placed electrodes in patients with drug refractory gastroparesis. Gastrointest Endosc 2005;61:455-461.

49 Elfvin A, Anderson S, Abrahamsson H, et al: Percutaneous implantation of gastric electrodes-a novel technique applied to animals and in patients. Neurogastroenterol Motil 2007;19:103-109.

>50 Yin J, Chen JZ: Implantable gastric electrical stimulation: ready for prime time? Gastroenterology 2008;134:665-667.

51 Ang D, Tack J: Gastric Electrical Stimulation for the treatment of gastroparesis: ready for prime time? Digestion 2007;75:80-82. 